\title{
DO ESTRANGULAMENTO EXTERNO À MORATÓRIA: A NEGOCIAÇÃO BRASILEIRA COM O FMI NO GOVERNO FIGUEIREDO (1979-1985)
}

\author{
Ivan Salomão ${ }^{a}$

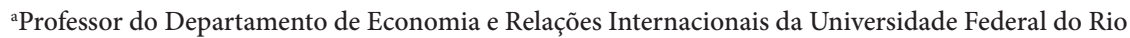 \\ Grande do Sul (UFRGS).
}

Artigo recebido em 28/12/2014 e aceito em 10/12/2015.

RESUMO: O processo de endividamento externo adotado nos anos 1970 esteve diretamente associado à necessidade de financiamento do II PND. A necessidade de legitimação do regime discricionário compeliu o governo a inserir a economia brasileira de modo imprudente no circuito financeiro internacional. Após o segundo choque do petróleo, em 1979, a política econômica da tecnocracia resumiu-se a administrar a crise do balanço de pagamentos. Estabeleceu-se, então, uma longa e hesitante negociação com o FMI e com os credores internacionais, e as divergências dela decorrentes ensejaram a decretação da moratória da dívida externa anos depois.

PALAVRAS-CHAVE: dívida externa; FMI; governo Figueiredo.

CLASSIFICAÇÃO JEL: F34. 


\title{
FROM EXTERNAL STRANGULATION TO MORATORIUM: THE BRAZILIAN NEGOTIATION WITH IMF IN FIGUEIREDO'S ADMINISTRATION (1979-1985)
}

\begin{abstract}
External indebtedness process adopted in the 1970s was directly associated with borrowing of the II PND. The need for legitimacy of discretionary regime compelled the government to enter the Brazilian economy recklessly in the international financial system. After the second oil shock in 1979, the economic policy of technocracy came down to manage the balance of payments crisis. It was established, then, a long and hesitant negotiation with the IMF and international creditors, whose differences entailed tried the declaration of moratorium on foreign debt years later.
\end{abstract}

KEYWORDS: foreign debt; IMF; Figueiredo administration. 


\section{INTRODUÇÃO}

O acelerado crescimento econômico observado em grande parte das duas décadas do regime militar serviu como uma dos principais pilares de legitimação do governo discricionário. Além de acomodar os conflitos sociais, o expressivo crescimento do PIB per capita, principalmente durante o "milagre", permitiu uma ascensão à classe média nunca antes vista na história recente do país de parcela não desprezível da população.

A instabilidade do fenômeno tornou-se clara, porém, quando do primeiro óbice externo. O choque do petróleo (1973) submeteu a tecnocracia à escolha de duas estratégias necessariamente excludentes: o ajuste recessivo ou o ajuste estrutural. A opção pelo II PND logrou concluir a penúltima etapa do processo de industrialização por substituição de importações. O endividamento necessário para viabilizar o plano, por seu turno, fez do Brasil o maior devedor entre todos os países do mundo.

O processo de endividamento externo levado a cabo no final dos anos 1970 pode ser subdividido em dois momentos: a partir de 1974, devido às vicissitudes da crise internacional, observou-se uma clara deterioração das condições de captação de recursos estrangeiros. De 1978 em diante, contudo, os deficit apresentados pela economia norte-americana e os "petrodólares" que irrigavam os bancos com atuação internacional permitiram que o governo brasileiro aprofundasse uma imprudente estratégia de endividamento.

Quando da segunda crise do petróleo, entretanto, o colapso do sistema financeiro internacional, aliado à subida vertiginosa dos juros nas economias centrais, fez com que a política econômica do último governo militar se restringisse apenas a administrar a crise do balanço de pagamentos. As severas restrições que o estrangulamento externo impôs à economia brasileira elucidariam a irresponsabilidade de se ter patrocinado um plano maiúsculo de investimentos baseado, eminentemente, em recursos estrangeiros.

Nesse sentido, este trabalho tem o objetivo de problematizar o processo de negociação do governo brasileiro com os credores externos, com destaque para o Fundo Monetário Internacional, durante o governo Figueiredo (1979-1985). Para tanto, dividiu-se o artigo em quatro partes, além desta breve introdução. $\mathrm{Na}$ seção 2, discorre-se acerca das contas externas no primeiro quinquênio da década de $1980 . \mathrm{Na}$ seção 3, aborda-se a negociação com o FMI propriamente dita. Na sequência, na seção 4 apresenta-se o debate acerca da viabilidade de se decretar a moratória da dívida externa como estratégia de barganha. Por fim, na seção 5 tecem-se as considerações finais. 


\section{O SETOR EXTERNO DA ECONOMIA BRASILEIRA NA PRIMEIRA METADE DOS ANOS 1980}

O encerramento do período consagrado pela literatura como "milagre econômico" (19681973) não viria desacompanhado de consequências onerosas. O robusto crescimento econômico que justificou a alcunha mítica resultou em aumento significativo da dependência externa do país. O primeiro choque do petróleo (1973) impôs rígidos condicionantes ao desempenho da economia brasileira. O cenário adverso foi atenuado pela expressiva entrada dos chamados "petrodólares" e pela percepção de que o Brasil representava um devedor seguro por parte dos bancos estrangeiros. A abundância de liquidez permitiu financiar os deficit em transações correntes sem que se percebesse a dramaticidade da conjuntura hodierna, elevando a já vultosa dívida externa brasileira (CARNEIRO, 1992).

Diante desse cenário de instabilidade, o governo que assumiu a presidência em março de 1974 contava com duas alternativas necessariamente excludentes para levar a cabo o ajuste externo que se mostrava inevitável: ajustamento ou financiamento. A opção adotada foi materializada pelo II Plano Nacional de Desenvolvimento (II PND). Tratava-se de um ousado plano de investimentos públicos e privados em setores classificados como "pontos de estrangulamento", tais como: exportação, infraestrutura, bens de capital e insumos básicos, com destaque para metalurgia e petroquímica.

As consequências negativas do II PND constituem um dos raros consensos entre os autores das mais diferentes escolas do pensamento econômico. O plano contribuiu em larga escala para o agravamento da dependência externa da economia brasileira, situação que esteve na base do agravamento dos conflitos distributivos e da aceleração inflacionária dos anos 1980.

De forma esquemática, pode-se caracterizar o processo de endividamento durante a década de 1970 em cinco pontos: (i) eliminação ou redução dos controles sobre a entrada de crédito externo; (ii) introdução de incentivos adicionais à captação no exterior (redução drástica do imposto sobre juros remetidos ao exterior); (iii) estatização do risco cambial $^{1}$; (iv) manutenção de uma política monetária que estimulasse a captação externa; e (v) maciça utilização do setor público para a atração de divisas (BATISTA JÚNIOR, 1981).

Não obstante, os tempos de cigarra não tardaram a cobrar o seu preço. A abrupta elevação das taxas de juros internacionais que se seguiu ao segundo choque do petró-

\footnotetext{
Apesar de a dívida externa brasileira ter nascido e ganhado vulto sob a forma predominantemente pública, a Resolução 432 do Banco Central, emitida em 1977, em muito contribuiu para que passassem a recair sobre o governo os cada vez mais pesados ônus do serviço da dívida. Por ela, permitiu-se aos tomadores privados a possibilidade de depositar antecipadamente o contra-valor em cruzeiros de seu débito externo em uma conta aberta no BC, o qual passaria a responder pelos juros, spreads e correção cambial da dívida (MELLO e BELLUZZO, 1983, p. 16). Para uma análise minuciosa da evolução da dívida pública no período, ver, por exemplo, Biasoto Junior (1988); Campos (1999); Fishlow (1986); Cruz (1984) e Carneiro (1994).
} 
leo (1979) desencadeou a maior recessão já vivida pelos países industrializados desde o pós-Segunda Guerra. A consequente queda na demanda pelos produtos que compunham a pauta de exportações brasileira mostrou-se fatal para o já asfixiante deficit do balanço de pagamento em transações correntes. Selar-se-ia, a partir de então, o sepultamento da quase cinquentenária era de robusto crescimento econômico do Brasil.

Diante da progressiva deterioração apresentada pelos indicadores macroeconômicos desde o início de 1980 - com destaque negativo para os números das contas externas - não tardou para se fazer presente a inflexão da política econômica do governo brasileiro. Ao final do primeiro ano da década, a incursão heterodoxa ${ }^{2}$ cedia espaço a um explícito ajuste contracionista nos moldes propostos pelo FMI. Desse ponto em diante, as linhas gerais da política econômica do último governo militar passaram a ser ditadas pela disponibilidade de financiamento externo. Conforme assinalam Carneiro e Modiano (1992), o fracasso do breve suspiro herético resultou em demonstração contínua de fé ortodoxa ${ }^{3}$ nos controles de demanda como forma de lidar com a inflação e com os deficit em conta corrente.

A brusca alteração na condução da economia brasileira respondeu ao agravamento da crise internacional. A escalada vertiginosa das taxas de juros nos países desenvolvidos ao longo do triênio 1979-1981 subjazia a meia-volta do ministro Delfim Netto. A desvalorização do dólar durante a década de 1970 fora tão expressiva que, em março de 1980, o Federal Reserve (Fed) lançou um pacote monetário fortemente contracionista a fim de conter a sua depreciação. Segundo Furtado (1984), em nenhuma outra parte do globo os efeitos da corrente crise foram tão severos quanto no Brasil, pois à antiga dependência de importação de petróleo somava-se agora um vultoso pagamento de juros e amortizações aos credores externos.

$\mathrm{O}$ arrocho tinha por objetivo promover o ajuste externo através da redução da absorção interna a fim de que fossem gerados excedentes exportáveis. Para tanto, recorreu-se a uma política monetária altamente restritiva que, se por um lado promoveu a contração dos investimentos, por outro estimulou as empresas a recorrerem ao mercado de crédito internacional, o que, por sua vez, convinha à tão necessária atração de divisas em moedas conversíveis.

\footnotetext{
Compuseram o pacote não convencional dos dois primeiros anos do governo as seguintes medidas: subsídios às exportações, extinção do depósito prévio, relaxamento dos critérios de similaridade, fim dos juros subsidiados e desvalorização cambial (BADO, 1991).

3 Já se faziam representados, ainda que de maneira velada, os interesses dos credores externos na nova conduta da Seplan. De acordo com Moura (1990, p. 46), a "mudança na política econômica em 1980 não resultou da força da competição de grupos políticos organizados, mas sim das pressões emanadas do sistema financeiro internacional privado".
} 
Como era de se esperar, o ajuste não veio desacompanhado de consequências onerosas. O ano de 1981 foi, em toda historiografia nacional estatisticamente documentada, o primeiro em que se registrou queda real no produto (- 4,25\%). As condições ainda mais severas a que o país se sujeitou até o final do governo Figueiredo incitaram Celso Furtado (1983) a apontar para o início dos anos 1980 como sendo o período da mais severa crise da história republicana brasileira.

Essa nova realidade não foi interpretada pelos técnicos do governo como um revés pontual, uma vez que o cenário externo não emitia sinais de que seriam atenuadas as condições de financiamento no curto prazo. Pelo contrário. O ano de 1982 marcou o aprofundamento da crise internacional ${ }^{4}$ e, em decorrência da progressiva escassez de reservas cambiais, a radicalização das medidas recessivas impostas pelo governo.

Em agosto daquele ano, a dívida de curto prazo em muito já superava os aproximadamente US\$ 7 bilhões das reservas internacionais do Banco Central; no mês subsequente, não suportavam mais do que dois meses de importações (RESENDE, 1982). A esses dados podem ser adicionados ainda outros agravantes ${ }^{5}$. De acordo com Batista Júnior (1983), os números divulgados referentes às reservas da autoridade monetária estavam equivocados ou, no mínimo, superestimados. Segundo o autor, as obrigações de curto prazo simplesmente passaram a não ser contabilizadas, o que, por si só, ultrajaria ainda mais a já frágil posição brasileira. Além disso, as reservas cambiais não refletiam de modo adequado a disponibilidade efetiva de liquidez internacional, pois contavam com ativos eventualmente não conversíveis.

\begin{tabular}{|c|c|c|}
\hline Ano & Reservas Internacionais & Dívida Externa \\
\hline 1981 & $7.507,00$ & $61.411,00$ \\
\hline 1982 & $3.994,00$ & $70.197,00$ \\
\hline 1983 & $4.563,00$ & $81.319,00$ \\
\hline 1984 & $11.995,00$ & $91.091,00$ \\
\hline 1985 & $11.608,00$ & $95.857,00$ \\
\hline
\end{tabular}

Fonte: Elaboração própria com base em dados de Ipeadata.

4 A crise financeira internacional não se restringiu apenas aos entes públicos, mas se alastrou também entre importantes corporações privadas dos EUA e da Europa Ocidental, dentre as quais chegaram à concordata as alemãs Telefunken e Pelikan, as canadenses Massey Fergunsson e Dome Petroleum, a norte-americana International Harvester, entre outras (PORTELLA FILHO, 1998).

5 Batista Júnior (1983) oferece estudo pormenorizado sobre a incorreção dos dados referentes às contas externas divulgados pelo Banco Central do Brasil durante a primeira metade dos anos 1980 . 
Contribuiu para deteriorar ainda mais esse quadro interno a ocorrência, ao longo de 1982, de uma série de episódios políticos e econômicos no restante do globo. O primeiro deles esteve relacionado à situação de pré-colapso cambial em que diversos países do mundo socialista incorreram durante aquele ano - tendo o caso da moratória polonesa ocupado posição de destaque em virtude do nível de endividamento externo a que esse país havia se submetido. A América do Sul também esteve diretamente envolvida na desestabilização econômica do continente. A deflagração do conflito militar no Atlântico Sul no início de abril, em virtude da disputa pelo território argentino das Malvinas, contribuiu para abalar o já rigoroso programa brasileiro de ajustamento externo. A paralisação do comércio bilateral com o país atacado, o mais relevante parceiro econômico do Brasil após os Estados Unidos, em muito prejudicou os resultados do balanço de pagamentos em transações correntes.

A esse cenário veio se somar o derradeiro crash mexicano. No dia 23 de agosto de 1982, o governo desse país anunciou oficialmente a sua situação de inadimplência. O impacto do default do segundo maior devedor latino-americano paralisou o fornecimento de crédito externo voluntário aos países devedores ${ }^{6}$. Como a quebra de um encanto, inverteu-se imediatamente a avaliação dos bancos estrangeiros com relação aos empréstimos internacionais. Na tentativa de solucionar o impasse, o Fundo Monetário Internacional reuniu-se às pressas no início do mês seguinte em Toronto, Canadá. $\mathrm{O}$ fracasso desse encontro contribuiu para acirrar ainda mais o ânimo do mercado financeiro internacional (RESENDE, 1982).

A gravidade da situação exigia medidas emergenciais a fim de que se evitasse o desencadeamento de outras suspensões unilaterais. Ainda que o processo de endividamento externo do Brasil tenha sido mais bem administrado do que os casos mexicano e argentino - no que concerne à distribuição das obrigações ao longo do tempo -, a situação de todos os países devedores tornou-se dramática a partir de setembro. $\mathrm{O}$ fechamento das contas externas passou a requerer uma verdadeira operação de salvamento, ocasião em que os chamados empréstimos-ponte ${ }^{7}$ fornecidos por organismos multilaterais, como o Fundo e o Bank for International Settlements (BIS), pelo Tesouro norte-americano e pelos próprios bancos comerciais se fizeram cruciais (MALAN, 1983).

O socorro ao FMI mostrava-se inescapável. Diante de indícios tão eloquentes de asfixia da economia brasileira, quais teriam sido, portanto, os motivos que induziram o

\footnotetext{
6 Na esteira da interrupção dos fluxos voluntários de crédito, mais de quarenta países em desenvolvimento foram obrigados a interromper ou reescalonar suas dívidas (BATISTA JÚNIOR, 1988).

Esse mecanismo de emergência consistia em contratar novos empréstimos, a custos significativamente mais altos, para honrar pontualmente os juros devidos por empréstimos passados (BACHA, 1983).
} 
governo brasileiro a postergar o acordo com o Fundo? Mello e Belluzzo (1983) reforçam a hipótese do raciocínio político. Para os autores, não se temia a imposição de mudanças drásticas através de uma estratégia de ajuste estrutural de longo prazo. Receava-se, este sim, o impacto eleitoral da assunção de fragilidade inerente aos governos que recorrem ao FMI. Furtado (1983) endossa essa argumentação ao afirmar que a rápida modificação do perfil da dívida externa não tinha explicação senão no empenho desesperado de adiar a renegociação das condições de pagamento para após as eleições realizadas em outubro. Dado que os países que negociam o fazem em situação de pré-insolvência, oferecendo aos banqueiros posição de força, pode-se afirmar que o Brasil optou pelo momento mais inadequado para assumir a renegociação de seus débitos.

Com efeito, o governo, de posse da calculadora político-eleitoral, adiou qualquer anúncio de aproximação com o Fundo para depois do pleito a fim de não se mostrar debilitado no momento da eleição do Congresso Nacional imbuído de escolher o próximo presidente da República. Dias após o escrutínio, enquanto ainda se contabilizavam os votos, finalmente o ministro Delfim Netto assumiu estar em negociação com o órgão, rendição necessária para evitar - ou retardar, como provaria a história - a ruptura com o sistema financeiro internacional.

Seja pela severidade da crise, seja pela falta de credibilidade das autoridades econômicas brasileiras, a situação do governo brasileiro era, de fato, penosa. Tavares e Assis (1985) apontam para um cenário desolador ao descrever a situação em que se encontravam as autoridades brasileiras àquele momento: "apanhada de surpresa (pela moratória do México), incapaz ideologicamente de vislumbrar um projeto alternativo e sem base política para propô-lo, a equipe econômica perdeu totalmente a iniciativa até capitular diante de FMI". O regime dito "revolucionário" promovera inserção profunda da economia brasileira no sistema financeiro internacional para mais tarde reconhecer ter-se tornado seu refém.

Foi nesse contexto de emergência que o Conselho Monetário Nacional (CMN) publicou, em 25 de outubro de 1982, a "Programação do Setor Externo para 1983". Tratava-se, basicamente, da elevação a graus asfixiantes das medidas recessionistas adotadas havia dois anos. Pelas propostas do governo, o país geraria naquele ano superavit comercial da ordem de US\$ 6 bilhões, de modo que as importações deveriam ser comprimidas a US\$ 17 bilhões e as exportações elevadas ao nível de US\$ 23 bilhões. Esses resultados representariam uma contração de $17 \%$ nas primeiras e um aumento de 9,5\% nas segundas (ARIDA, 1982).

Para Lago (1982), soaria factível elevar as exportações a esse patamar fossem outras as condições da demanda externa que não as que se vislumbravam para aquele ano. O "teto" atingido pelas vendas brasileiras ao exterior devia-se à retração da demanda nos mercados consumidores e aos preços relativos dos produtos nacionais, e 
não a outros motivos pontuais que poderiam ser facilmente suplantados (CARNEIRO, 1992). Já para as importações, reprimir a aquisição de bens e serviços do exterior a essa monta constituir-se-ia tarefa de difícil execução, uma vez que não havia sido observada tamanha redução nas duas décadas anteriores e que o nível das importações já vinha declinando havia anos ${ }^{8}$.

Tabela 2 - Exportações, importações e saldo da balança comercial (FOB), Brasil, 1981-1985 (em milhões de US\$)

\begin{tabular}{lccc}
\hline Ano & Exportações & Importações & Balança Comercial \\
\hline 1981 & $23.293,04$ & $22.090,58$ & $1.202,46$ \\
1982 & $20.175,07$ & $19.395,00$ & 780,07 \\
1983 & $21.899,31$ & $15.428,93$ & $6.470,39$ \\
1984 & $27.005,34$ & $13.915,82$ & $13.089,52$ \\
1985 & $25.639,01$ & $13.153,49$ & $12.485,52$ \\
\hline
\end{tabular}

Fonte: Elaboração própria com base em dados de Ipeadata.

A contração resultou em um claro sacrifício à já combalida economia do país. Bacha (1982) estimou que cada dólar economizado na importação de bens de capital custaria uma diminuição equivalente a cinco dólares na produção nacional. É nesse sentido que Furtado (1989, p. 50) sentenciou que "o processo recessivo paga a dívida em dobro: com o que se manda para fora e com o que se deixa de produzir em razão da recessão". A intensidade do ajuste acarretou, na avaliação de Camargo (1982), uma situação irônica para um país de industrialização tardia e induzida pelo Estado: a estrutura produtiva não podia ser plenamente utilizada devido à falta de divisas para financiar as importações decorrente de tal medida. Após três anos de estagflação, observou-se em 1984 o relaxamento das restrições externas que em muito haviam contribuído para a recessão dos anos anteriores. O crescimento vigoroso da economia norte-americana mostrou-se decisivo para que, em 1985, o saldo comercial atingisse a marca recorde de US\$ 12 bilhões?.

Ao final do governo Figueiredo, o ajustamento externo pôde ser considerado bem-sucedido devido à geração dos vultosos superavit comerciais. Por outro lado, a estratégia recessiva "sugerida" pelo FMI baseara-se na redução do investimento público, na aceleração das desvalorizações cambiais e em uma política monetária extremamente austera. A resolução paliativa dos constrangimentos externos, conforme apontam

8 Não se podia ignorar que, naquele momento, tratava-se o Brasil de um país de coeficiente de importações extremamente baixo. Segundo Furtado (1983), o valor das importações em 1982 correspondeu a 7,6\% do PIB, fração que demonstrava a sua elevada essencialidade.

9 Naquele ano, as importações da maior economia do mundo cresceram 26\%, ampliando o deficit em transações correntes desse país para US\$ 188 bilhões (BAER, MACARINI e ANDRADE, 1986). 
Camargo e Ramos (1990), foi obtida, ao menos em parte, às custas de um aumento do desequilíbrio interno cujos resultados mais visíveis foram a queda nos salários reais e do aumento dos níveis de desemprego.

Em decorrência da política de endividamento levada a cabo até o final da década de 1970 - e, daí em diante, como resultado dos vultosos pagamentos de juros resultantes desse processo -, a dívida externa brasileira beirava, ao final de 1985, o valor de US\$ 100 bilhões. A quem coube a responsabilidade por esse quadro que tantas restrições impôs à economia brasileira nas duas décadas seguintes? Para Portella Filho (1998), o crescimento vultoso da dívida merecia uma auditoria a fim de se verificar quem dele se beneficiou, uma vez que, segundo o autor, nem as importações de petróleo, nem os projetos de desenvolvimento justificam um endividamento tão profundo em tão pouco tempo ${ }^{10}$.

Tabela 3 - Transações correntes, conta capital e saldo do balanço de pagamentos Brasil, 1981-1985 (em milhões de US\$)

\begin{tabular}{lccc}
\hline Ano & Transações Correntes & Conta Capital & Balanço de Pagamentos \\
\hline 1981 & $-11.705,87$ & $12.745,74$ & 624,70 \\
1982 & $-16.273,20$ & $12.100,73$ & $-4.541,60$ \\
1983 & $-6.773,03$ & $7.418,76$ & $-24,20$ \\
1984 & 94,91 & $6.529,19$ & $7.026,70$ \\
1985 & $-248,34$ & 196,56 & $-456,60$ \\
\hline
\end{tabular}

Fonte: Elaboração própria com base em dados de Ipeadata.

O primeiro ano da Nova República não veio acompanhado de mudanças significativas na administração das contas externas. A ambiguidade com que Tancredo Neves lidava com a questão da dívida externa ${ }^{11}$ - provavelmente em função do leque politicamente heterogêneo com o qual governaria - refletiu-se nas medidas inicialmente contidas implementadas pelo novo governo. O comando da economia havia sido delegado ao ex-secretário da Receita Federal, economista de formação ortodoxa, Francisco Dornelles. Politicamente fragilizado, o presidente José Sarney acatou suas diretrizes avalizando uma agenda de austeridade no combate à inflação e de apaziguamento no trato da dívida externa durante o primeiro semestre de 1985.

${ }^{10}$ Há ainda os que negavam a legitimidade de uma dívida contratada por governantes não eleitos através do voto direto. Rudi Arndt, vice-presidente da bancada socialista no parlamento europeu e ex-prefeito de Frankfurt, defendia que governos democráticos da América Latina não deveriam assumir a dívida contraída por regimes ilegítimos ou ditaduras (BRANT, 1986).

11 Tancredo expôs calculadamente a dubiedade com que tratava do tema na reunião que o Secretário de Estado norte-americano agendou sobre o tema. George Schultz viera ao Brasil, em outubro de 1984, exclusivamente para sondar as intenções dos dois postulantes ao Planalto acerca da questão. E obteve do candidato oposicionista a pouco esclarecedora reposta: "Não há nada a mudar na nossa política externa. Apenas ela será acrescida pelo estilo pessoal do presidente" (DIMENSTEIN et al., 1985, p. 163). 
Sob Dornelles, a política econômica não sofreu alterações de rota, apenas correções de percurso em relação àquela levada a cabo por Delfim Netto nos anos anteriores. Contida, mas não frugal. Responsável, porém, aquém do que a conjuntura interna requeria. O esgotamento dessa meia-estratégia - que não chegou a lograr seus objetivos econômicos, e que ainda por cima, impôs significativos reveses políticos - custou o cargo do ministro da Economia e encerrou o período em que a benevolência balizou as negociações com os credores externos.

Em relação ao balanço de pagamentos, Sarney tomou posse em um momento de rara calmaria devido ao mega-superavit comercial obtido em 1984. Além do consequente acúmulo de reservas cambiais, aguardava o novo governo um cenário internacional extremamente otimista. Os países industrializados prosseguiram em 1985 sua trajetória de crescimento iniciada em 1983, permitindo que o comércio mundial encerrasse o ano com um crescimento de 3,5\% sobre o anterior, no qual já havia sido registrado um aumento de 8,5\% (BAER, MACARINI e ANDRADE, 1986).

Pode ser arrolada ainda uma série de outros fatores conjunturais que corroboravam as perspectivas favoráveis em relação ao quadro externo: a contínua desvalorização do dólar frente à maioria das moedas; a melhoria dos termos de troca via redução dos preços dos produtos importados; a queda expressiva das taxas de juros internacionais; a redução dos encargos da balança de serviços, entre outros fatores (SAMPAIO JÚNIOR e AFFONSO, 1986).

\section{A NEGOCIAÇÃO COM O FMI DURANTE O GOVERNO FIGUEIREDO (1979-1985)}

Ao primeiro contato das autoridades brasileiras com a diretoria do FMI, em dezembro de 1982, seguiu-se uma longa e tortuosa negociação - à qual posteriormente veio a se somar o comitê de assessoramento dos bancos credores $^{12}$ - que se estendeu até meados da década de 1990. Foge ao propósito deste trabalho a apreciação das condições em que foram prorrogados os acordos durante esse período. Faz-se oportuna, contudo, uma breve análise cronológica dos meandros que envolveram essa litigiosa relação, os quais, em grande medida, contribuíram para que fosse decretada a moratória no governo subsequente.

12 Compunham o comitê de assessoramento representantes de 14 bancos estrangeiros, sendo sete norte-americanos e mais um integrante de cada instituição dos seguintes países: Canadá, Japão, Inglaterra, França, Alemanha, Suíça e Arábia Saudita. Constituído, ao menos em teoria, para "assessorar" os negociadores brasileiros, esse grupo teve todas as suas despesas operacionais pagas pelo governo brasileiro durante o tempo que se manteve estabelecido (NEPOMUCENO, 1990). 
Durante os quatro anos compreendidos entre o envio da primeira carta de intenções ao Fundo até a moratória do governo Sarney (decretada em fevereiro de 1987), o processo de renegociação da dívida externa pôde ser dividido em quatro fases: (i) dezembro de 1982 a julho de 1983; (ii) julho de 1983 a setembro de 1984; (iii) setembro de 1984 a setembro de 1985; e (iv) setembro de 1985 a fevereiro de 1987.

A primeira etapa respondeu aos efeitos decorrentes do colapso do mercado de crédito voluntário após o chamado "setembro negro". Naquele momento, os técnicos do governo brasileiro acreditavam que se estava diante de uma crise de liquidez, e não exatamente de solvência. Para a equipe econômica, a solução não requeria, portanto, medidas de maior alcance, tendo o país ultrapassado os primeiros meses à base dos empréstimos-ponte concedidos pelo Tesouro norte-americano e por um grupo restrito de bancos comerciais. O objetivo secundário dessa aparente passividade perante uma conjuntura que se mostrava problemática era o de tranquilizar o mercado financeiro internacional.

Para isso, paralelamente ao esforço voluntário proposto pelas autoridades do CMN - o qual incitou diversos analistas a trazerem à tona a ideia de uma moratória técnica -, gestava-se um acordo formal com o FMI para os três anos seguintes ${ }^{13}$. No dia 20 de dezembro de 1982, o presidente do Banco Central reuniu-se com autoridades bancárias norte-americanas para apresentar as cláusulas da proposta que seria apresentada ao Fundo - documento, este, considerado como o aval indispensável à reabertura da negociação com a comunidade financeira internacional. Na carta que seria encaminhada à diretoria do órgão no início de janeiro ${ }^{14}$, o governo se comprometia a aprofundar as medidas contracionistas em troca de um acordo plurianual com os credores conhecido como "os quatro projetos", os quais viriam a balizar toda a negociação durante a década de 1980. Em contrapartida, o FMI se comprometeria a injetar US\$ 4,2 bilhões na conta capital do balanço de pagamentos brasileiro.

O primeiro projeto previa novos empréstimos no valor de US $\$ 4,4$ bilhões através dos quais os bancos financiariam parte dos juros devidos a eles mesmos. O "dinheiro novo" seria liberado em quatro parcelas ao longo de 1983. O projeto dois referia-se aos recursos destinados à amortização do principal da dívida de médio e longo prazos, no valor de US\$ 4,6 bilhões. No terceiro, tratava-se das linhas de crédito comercial relacionadas às importações e exportações, em um total de US\$ 8,8 bilhões. E o último

\footnotetext{
${ }^{13}$ Furtado (1983, p. 66) referiu-se aos contatos pré-eleitorais que o governo já havia mantido com a diretoria do Fundo como "uma verdadeira negociação clandestina".

14 Foram enviadas, até o final do governo Figueiredo, outras seis cartas de intenções ao FMI na seguinte ordem cronológica: 6 de janeiro de 1983, 24 de fevereiro de 1983, 15 de setembro de 1983, 14 de novembro de 1983, 15 de março de 1984, 28 de setembro de 1984 e 20 de dezembro de 1984 (MARQUES, 1988).
} 
contemplava os créditos interbancários de curto prazo das agências dos bancos brasileiros no exterior, no montante de US\$ 9,4 bilhões (MUNHOZ, 1983).

Os critérios de desempenho da primeira carta haviam sido formulados com uma expectativa de inflação de $70 \%$ para o ano de 1983. Ao final de dezembro, porém, a elevação dos preços atingiu a marca de $211 \%$, o que, na prática, inviabilizou o cumprimento de suas metas. A desobediência ao acordo já no primeiro trimestre do ano fez com que o FMI não liberasse a segunda parcela de US\$ 400 milhões prevista para maio. Como consequência, acumularam-se pagamentos devidos ao exterior, situação que precipitou o encerramento dessa primeira etapa das negociações (RESENDE, 1983).

A segunda fase teve início no último semestre de 1983, por ocasião da formação de um novo comitê de assessoramento dos bancos credores, o qual passou a ser presidido exclusivamente pelo Citibank. Nas três cartas de intenções enviadas ao Fundo Monetário durante essa etapa, propôs-se a manutenção dos mesmos “quatro projetos" estabelecidos no início de 1983, com a adição de determinadas novidades pontuais, as quais resultaram na redução dos spreads e no alargamento dos prazos.

Em outubro daquele ano, o governo brasileiro obteve do Congresso Nacional a aprovação de uma reforma de desindexação salarial cujo resultado óbvio em termos de achatamento da renda do trabalho agradou ao staff do Fundo. Duas semanas depois, foram liberadas as parcelas dos empréstimos até então retidas, tanto pelo FMI quanto pelos bancos comerciais, com os quais o governo saldou os empréstimos-ponte que haviam sido concedidos pelo BIS e pelo Tesouro norte-americano em 1982.

Ainda assim, a deterioração da posição externa da economia brasileira ao longo do ano levou o governo a adotar medidas que visavam ao maior controle cambial. No final de julho, o Banco Central havia publicado instrução que determinava a monopolização das compras de divisas por parte da autoridade monetária, a qual passou a estabelecer critérios administrativos para a liberação dos pagamentos (BACHA, 1987). A regulamentação não surtiu os efeitos esperados de curto prazo, contudo. Em dezembro, o país encerrava seu terceiro ano consecutivo de grave recessão econômica: a renda per capita havia regredido aos níveis de 1976; a produção, ao patamar de 1977; e o emprego industrial, em São Paulo, às taxas observadas em 1973 (PACHECO, 1986).

Quando da formulação da já citada programação do setor externo em outubro de 1982, as autoridades nacionais haviam se mostrado excessivamente otimistas com as expectativas para o ano vindouro. O recente trauma do colapso mexicano foi minimizado ao mesmo tempo em que se superestimou a capacidade de ajustamento das contas externas brasileiras no curto prazo. Malan (1983) aponta ainda para outro equívoco cometido pela equipe econômica do governo: a assunção de que o acordo com o Fundo representava uma medida meramente pró-forma. O não cumprimento das metas influenciou de maneira decisivamente negativa o impasse na negociação com os bancos credores em 1983. 
O ano seguinte foi marcado por uma fugaz melhora nas contas do balanço de pagamentos. O desempenho extraordinário das exportações brasileiras em 1984 (US\$ 27 bilhões, contra os já expressivos US\$22 bilhões do ano anterior) recompôs a posição externa do Banco Central, o qual encerrou o ano com valor superior a US\$ 7 bilhões de reservas internacionais. O fortalecimento cambial do país permitiu ao governo obter sucessivos "perdões" (waivers) pelo não cumprimento das metas creditícias e fiscais acertadas no programa de ajustamento com FMI em janeiro de 1983.

E foi nessa situação de relativa calmaria que, em setembro de 1984, por ocasião do envio da chamada "proposta Pastore" à diretoria do Fundo, iniciou-se a terceira fase da renegociação. Nesse período, a preocupação central foi reconstruir o perfil da dívida de médio e longo prazos, de modo a evitar a necessidade de novas renegociações com os bancos comerciais. Há que se destacar pelo menos duas conquistas obtidas na fase: em primeiro lugar, não se fez necessário o empréstimo de "dinheiro novo" para honrar os compromissos externos de curto prazo. Além disso, foi abolida a opção antes oferecida aos bancos de utilizarem a prime rate norte-americana como taxa de referência.

Em dezembro de 1984, o governo brasileiro chegou ainda a enviar a sétima e última carta de intenções, a qual sequer chegou a ser analisada pela diretoria do Fundo, contudo, em função da intratabilidade do problema fiscal brasileiro, da alta inflação e das incertezas que rondavam a sucessão presidencial. Aguardou-se, assim, pela nova equipe que assumiria o governo, em março de 1985, para dar seguimento às negociações ${ }^{15}$.

O Quadro 1 oferece uma breve comparação esquemática das três fases da renegociação da dívida com os credores externos e o FMI durante a gestão Figueiredo.

\section{Quadro 1 - Comparação das três fases de negociação da dívida externa brasileira} (continua)

\begin{tabular}{|c|c|c|c|c|}
\hline Projeto & Primeira fase & Segunda fase & Terceira Fase & Quarta fase \\
\hline Projeto 1 & 4,4 & 6,5 & - & - \\
\hline Projeto 2 & & & 16 & a ser negociado \\
\hline $\begin{array}{c}\text { Prazo de pagamento } \\
\text { (anos) }\end{array}$ & 8 & 9 & 7 & a ser negociado \\
\hline Carência & 2,5 & 5 & & \\
\hline
\end{tabular}

\footnotetext{
${ }^{15}$ Faz-se oportuno destacar que as vicissitudes pelas quais passou a negociação entre os representantes do governo brasileiro e o FMI não se deveram apenas aos termos estritos dos acordos de aporte financeiro. As contrapartidas em termos de política econômica exigidas pelo Fundo encontravam resistência por parte da equipe econômica brasileira. As divergências em relação à contabilidade nacional, por exemplo, eram robustecidas pela adoção de metodologias dissonantes, devido, em grande parte, à existência de quatro orçamentos do governo brasileiro: fiscal, monetário, das estatais e da previdência social. Para uma análise detalhada dessa questão, ver, por exemplo, a coleção organizada pela Gazeta Mercantil: $A$ armaditha da recessão (1983).
} 
Quadro 1 - Comparação das três fases de negociação da dívida externa brasileira (continuação)

\begin{tabular}{|c|c|c|c|c|}
\hline Projeto & Primeira fase & Segunda fase & Terceira Fase & Quarta fase \\
\hline $\begin{array}{c}\text { Taxa de juros + spread } \\
(\%)\end{array}$ & LIBOR +2,125 & LIBOR +2 & LIBOR + 1,125 & LIBOR + 1,125 \\
\cline { 2 - 4 } & Prime +1,875 & Prime + 1,75 & - & - \\
\hline Comissão (\%) & 1,5 & 1 & $985-1991$ & $1985-1986$ \\
\hline Período de consolidação & 1985 & 1984 & 45 & 10 \\
\hline $\begin{array}{c}\text { Recursos envolvidos } \\
\text { (US\$, bilhões) }\end{array}$ & 4,3 & 5,4 & 10 & 5,4 \\
\hline Projeto 3 (US\$, bilhões) & 10,4 & 9,8 & $\begin{array}{c}\text { Eliminação gradual de } \\
\text { US\$ 5,5 } \\
\text { bilhões do crédito } \\
\text { bancário e sua } \\
\text { transformação em } \\
\text { créditos comerciais }\end{array}$ & $\begin{array}{c}\text { Transformação de } \\
\text { US\$ 600 milhões }\end{array}$ \\
\hline Projeto 4 & US\$ 6 bilhões & US\$ 5,4 bilhões & \\
\hline
\end{tabular}

Fonte: Baer (1989).

\section{A REAÇÃO AO AJUSTE RECESSIVO: A MORATÓRIA COMO MEIO DE NEGOCIAÇÃO}

O documento publicado em outubro de 1982 pelo CMN foi duramente recriminado pela maioria dos analistas por considerar as metas ali estabelecidas de difícil execução. A crítica comum baseava-se no argumento de que a estratégia havia sido concebida sobre pressupostos equivocados: a contração draconiana não seria a solução para o problema da economia brasileira, pois não se estava diante de um problema de liquidez, mas sim de uma crise de solvência (MELLO e BELLUZZO, 1983).

Furtado (2006) aponta para esse mesmo erro ao afirmar que não se podia perder de vista o fato de que a crise global era de natureza estrutural e, portanto, não poderia ser tratada com medidas monetárias e fiscais destinadas a contrair a demanda no curto prazo. Para Arida (1982, p. 11), a recessão como estratégia era inadequada tanto para promover o ajuste quanto para reduzir o deficit público. Malan (1982, p. 108) endossa de maneira contundente esse argumento: já que não se tratava de uma crise de caráter conjuntural, o estrangulamento externo não seria superado através da recessão programada para 1983, "como sugeriam os mal informados, os malformados, ingênuos e os engenhosos otimistas-por-dever-do-ofício."

Opondo-se a esse realismo excessivo a que teriam se rendido as autoridades econômicas, Castro e Souza (1985) apontam três indícios para justificar sua discordância em relação às metas recessivas propostas pelo governo. O primeiro deles ressalta que a "velocidade" da economia em 1979 era menor se comparada à época do primeiro choque do petróleo. Além disso, a safra de investimentos do II PND já se encontrava em estágio avançado, e não havendo pretensões de se deslanchar nova onda de inversões, 
nada justificaria contração de tal monta. Por fim, seria inócua a iniciativa de se conter ainda mais a demanda por bens estrangeiros, uma vez que, conforme expressão por eles utilizada, as importações se encontravam "no osso"16.

Elevava-se o tom das críticas na medida em que se faziam perceptíveis os efeitos da retração da atividade econômica. Para Mello e Belluzzo (1983), era "criminosa" a ideia de que o Brasil poderia pagar a dívida pela ampliação continuada dos saldos da balança comercial, obtida à custa de recessão permanente. Furtado ${ }^{17}(1987$, p. 60) tece críticas não menos ácidas ao esforço megalomaníaco esboçado pelo governo: não haveria em parte alguma quem fosse "suficientemente ingênuo para crer que o Brasil iria pagar sua enorme dívida externa com magros saldos de balança comercial obtidos à custa da estagnação econômica". Ainda segundo o autor, "ninguém de bom senso e com um mínimo de espírito público poderia aceitar que a recessão fosse uma solução para os problemas brasileiros em face da crise mundial" (1983, p. 14).

Os pareceres depreciativos em relação ao documento provinham inclusive de economistas de reconhecido viés ortodoxo. Ao analisar a meta estabelecida para as necessidades de financiamento do setor público, as quais deveriam ser mantidas aos níveis reais do ano anterior, Bacha (1983, p. 89) concluiu que não era preciso "ser um fiscalista fanático para compreender o que tamanha contração fiscal significaria em termos de redução do nível de atividade e do emprego", pois se tratava de "austeridade demais para ganho nenhum" (1982, p. 178). Para o autor, "antes de dar receita para comprimir a demanda agregada e de ficar manipulando identidades contábeis, o staff do FMI deveria verificar é se havia ou não desemprego e capacidade ociosa nas indústrias potencialmente exportadores" (1983, p. 84).

Até mesmo aos burocratas do governo soavam excessivamente rigorosas as sugestões oferecidas pelo organismo multilateral e acatadas pelo governo brasileiro. O reconhecidamente contido ex-presidente do Banco Central, Carlos Langoni, não se furtou de assumir que "a política econômica que vem sendo adotada é socialmente injusta e economicamente ineficiente" (apud TAVARES e ASSIS, 1985, p. 82).

\footnotetext{
${ }^{16}$ Em 1982, nada menos que 78\% das importações brasileiras restringiram-se a combustíveis, lubrificantes e matérias-primas (CASTRO e SOUZA, 1985).

17 Diante da relevância da atuação do FMI durante todo o processo de renegociação da dívida externa brasileira, cabe registro da opinião que um economista com vasta e reconhecida atuação internacional, como foi Celso Furtado, reservava ao desempenho desse órgão: "O FMI sobreviveu como instrumento de tutela de países inadimplentes. Representa um progresso considerável com respeito à época em que os credores mandavam navios de guerra para ocupar as aduanas de países devedores em default. Mas o espírito é o mesmo: submeter a controle um Estado que se considera incompetente para gerir os próprios negócios" (1981, p. 83). "Mas a verdade é que a situação esdrúxula desse órgão [FMI] faz que o sistema das Nações Unidas se encontre destituído de meios para enfrentar o mais grave problema da economia internacional" (1987, p. 74, grifo nosso). "A experiência que adquiri no trato das políticas de desenvolvimento e na observação da atuação do FMI me autoriza a afirmar que essa instituição não dispõe da competência necessária para orientar o Brasil na busca de uma saída para a grave crise que enfrenta atualmente" (2006, p. 174).
} 
As repercussões do programa econômico para 1983 não se limitaram a críticas restritas ao meio acadêmico. As metas propostas pelo CMN ensejaram intenso debate acerca de políticas alternativas ao receituário ortodoxo. Parcela relevante das sugestões esboçava o que viria a ser a postura adotada pelo governo Sarney nos meses antecedentes à moratória, pois muitos dos autores que manifestaram contrariedade à estratégia de Delfim Netto integraram, anos mais tarde, a equipe responsável pelo default.

Núcleo central da argumentação de tais analistas, a assunção por parte das autoridades brasileiras de uma postura altiva frente aos credores internacionais já pressupunha o inevitável ambiente político e de confrontação em que a renegociação dos débitos seria posteriormente envolvida. Bacha (1983) atesta que somente a geração de um fato político consumado é que permitiria a superação do impasse em que o país se encontrava. Nesse sentido, Furtado (1987, p. 75) aponta para o balizamento que os governos nacionais - em especial, o norte-americano - passaram a oferecer aos banqueiros de maneira a justificar a extrapolação da negociação para além da esfera econômica: "os bancos já não atuam isoladamente e dificilmente se afastam das linhas definidas pelo governo. Não se deve ignorar esse aspecto político do problema”. Coutinho (1983) partia do mesmo pressuposto para defender que a negociação em busca de soluções viáveis teria que envolver os governos e as instituições internacionais, situando-se, portanto, no plano político.

O primeiro argumento não carecia de fundamentação histórica. Quando analisados os casos de determinados países que já haviam decretado algum tipo de moratória, fica claro o aspecto político com que contaram suas autoridades para a resolução do impasse. Como contrapartida do exitoso alijamento de grupos comunistas que tramavam tomar o poder em seu país, o general Hadji Suharto obteve, com o apoio decisivo dos Estados Unidos, o reescalonamento da totalidade da dívida indonésia por um prazo de 30 anos sem a necessidade de que fossem pagos os juros (FURTADO, 1983). A própria reação atipicamente condescendente do governo Reagan quando do calote mexicano de 1982 evidenciou que a dependência dos EUA em relação ao petróleo daquele país criara um precedente ${ }^{18}$.

\footnotetext{
18 Faz-se necessário esclarecer, no entanto, as devidas diferenças que os casos mexicano e indonésio guardavam em relação ao brasileiro. Por motivos históricos, geográficos e políticos, a economia mexicana mantinha uma relação de interdependência - produtiva, comercial e financeira - com os Estados Unidos, a qual conferia diversas especificidades à negociação da dívida externa desse país com os credores norte-americanos. Para um melhor entendimento do processo de endividamento mexicano, ver, por exemplo, Davis (1984) e Davis (1985). No que concerne à Indonésia, sua relevância geopolítica no contexto da Guerra Fria balizou de forma determinante a atuação diferenciada da diplomacia norte-americana nos desdobramentos políticos e econômicos desse país do sudeste asiático.
} 
Foi a partir da paralisia nos mercados financeiros internacionais que se sucedeu ao "setembro negro", contudo, que se passou a suscitar abertamente a possibilidade do calote brasileiro. Para Lago (1988), excluído o caminho convencional de recurso ao FMI, de se recorrer a empréstimos-ponte e de se promover uma desvalorização drástica da moeda nacional, a suspensão do pagamento se mostrava inevitável.

A praxe na celebração dos contratos internacionais de crédito foi resgatada por Furtado (1983, p. 17-18) para qualificar uma possível contraproposta do governo brasileiro: "os acordos financeiros que entidades privadas assinam com agentes soberanos trazem implícita a cláusula de que em situações especiais estes poderão modificar as condições de sua execução". Caberia, assim, ao devedor soberano declarar unilateralmente a moratória e oferecer opções ao credor privado. O autor já vislumbrava, dessa forma, o momento em que o serviço da dívida teria de ser suspenso por inanição da economia devedora. O problema que se colocava, portanto, não era o de saber se a dívida seria paga ou não, pois "é evidente que a suspensão do pagamento virá mais cedo ou mais tarde" (Furtado, 1989, p. 52).

Mello e Belluzzo ${ }^{19}$ (1983, p. 15) ressaltavam não apenas a conveniência, mas já alertavam para a necessidade de uma ruptura unilateral:

A moratória é considerada providência indispensável para criar outras bases de negociação. Ninguém deseja a moratória em si mesma, mas no ponto a que chegamos, o de moratória de fato, sem nenhum direito, não há outro caminho para escapar às vicissitudes cambiais. Ao mesmo tempo, tratando-se de instrumento legítimo e moralmente saudável, tratando-se de moratória para negociar, e não de repúdio da dívida, não se deve aguardar a insânia das represálias, mesmo porque já estamos sofrendo boa parte delas.

Igualmente incisivo, Coutinho (1983, p. 51-52) sugeria uma postura de afronta para solucionar os problemas cambiais de curto prazo: "ou bem os banqueiros nos refinanciam voluntariamente, ao longo dos próximos 3 [sic] anos, a totalidade dos juros devidos; ou bem deveria declarar-se a impossibilidade de pagamento destes, por este prazo". Seguindo a mesma lógica, assumia que "a única saída aberta para o Brasil é a de declarar-se, desde logo, em estado de moratória - o que já corresponde à verdade dos fatos". Essa reconhecida passividade na postura dos negociadores brasileiros também contribuiu para a manutenção do impasse. Para Kaletsky (1988), o principal

\footnotetext{
19 Dois anos depois, esses autores vieram a se tornar assessores do ministro Dilson Funaro e, como tais, influenciaram de maneira decisiva para que a suspensão dos pagamentos fosse finalmente adotada.
} 
motivo pelo qual os devedores ainda não haviam levado os banqueiros aos limites teóricos de sua capacidade de conceder empréstimos involuntários foi não os terem convencido de que a suspensão do pagamento da dívida era uma opção plausível, e, portanto, uma ameaça real.

Reforçava o argumento defendido em favor da ruptura o raciocínio defendido por Lopes (1982), para quem já seria menos oneroso entrar oficialmente em estado de inadimplência do que se se cumprisse o programa do governo para o ano de 1983. Em outubro de 1982, Malan (1982, p. 114) já alertava para a urgência da renegociação ao questionar se a recessão corrente "já não constituía sacrifício de custos superiores aos de se declarar formalmente incapacitado para enfrentar os compromissos da dívida".

Endossam essa percepção as duas situações as quais, de acordo com Batista Júnior (1983), justificariam a pontualidade nos pagamentos: quando se está apto a honrar os compromissos financeiros ou no caso de que fosse garantida a continuidade de novos créditos. Se, no aforismo de La Rochefoucauld, "a gratidão nada mais é do que a esperança de novos favores", a paralisação do fluxo de financiamento voluntário que havia se seguido ao colapso mexicano indultaria a descortesia de todos os países devedores.

Caso o governo brasileiro consentisse em declarar a moratória, algumas condições deveriam ser satisfeitas, contudo. Para Resende (1983), a suspensão deveria vigorar por um prazo de 90 dias - período máximo permitido para que os bancos não tivessem que transferir os créditos para os seus passivos -, de maneira que, assim, a decisão não fosse vista como uma medida de repúdio da dívida. Bacha (1983, p. 93) sugeria o mesmo paliativo: "se é verdade que já estamos US\$ 1 ou 2 atrasados, por que não organizar o atraso, suspendendo o pagamento de juros por três meses enquanto se procura chegar a um acordo realista?”. Na expressão de Kaletsky (1988), tratar-se-ia de uma "inadimplência conciliatória", a qual, se aceita pelos credores, poderia ser a solução para os problemas de ambas as partes, pois oferecia o equilíbrio entre a total cooperação com os bancos e a rejeição pura e simples da dívida.

Aos que repudiavam a ruptura enquanto evento político capaz de gerar melhores condições para o pagamento da dívida externa, Arida (1982, p. 204) oferecia justificativa perspicaz: "a política econômica é sempre economia e política ao mesmo tempo. Se a heterodoxia viola as relações vigentes de poder, como o faz, erradas estão as relações de poder e não a heterodoxia das medidas".

\section{CONSIDERAÇÕES FINAIS}

A estratégia de endividamento externo adotada pelo regime militar mostrou-se equivocada a partir da eclosão da primeira crise do petróleo. A dependência a que se havia 
submetido a economia brasileira foi paulatinamente aprofundada, no decorrer da década de 1970, na medida em que o governo se valia da liquidez internacional para financiar o II Plano Nacional de Desenvolvimento.

Quando do segundo choque do petróleo, em 1979, a opção que se lhe fizera disponível seis anos antes já não mais existia. À equipe econômica do presidente Figueiredo coube apenas e tão somente a pouco lisonjeira tarefa de administrar o pagamento dos débitos com os credores internacionais. O fechamento dos canais de rolagem da dívida após o calote mexicano, em 1982, impôs a necessidade de se adotar um ajuste recessivo de claro cunho ortodoxo, cujas consequências deletérias atuaram no sentido de deslegitimar ainda mais o governo autoritário.

Os descaminhos por que passou a negociação do governo brasileiro com os diversos interessados na questão (governo norte-americano, o staff do FMI, além, é claro, dos representantes dos próprios credores) selaram o insucesso da tentativa de se atenuarem os efeitos da crise. $\mathrm{O}$ excessivo rigor imposto pelos credores, aliado à reiterada aptidão por parte do governo de descumprir os termos dos acordos pontuais, viria a implodir os canais de negociação anos mais tarde.

À medida que a crise econômica se somava à insatisfação política, passou-se a aventar em diferentes meios - entre analistas, intelectuais, políticos e no seio da própria tecnocracia - a possibilidade de se interromper o pagamento do serviço da dívida externa brasileira com os credores privados. Conquanto a situação das contas externas brasileiras se mostrasse seguramente frágil no triênio 1982-1984, não havia ambiente político para o governo brasileiro patrocinar a ruptura unilateral. Somente a necessidade premente de se legitimar perante a sociedade brasileira fez com que o governo indiretamente eleito, em 1985, vislumbrasse a oportunidade de chancelar a moratória, em fevereiro de 1987.

\section{REFERÊNCIAS}

ARIDA, P. "Austeridade, autotelia e autonomia". In: ARIDA, P. (Org.). Dívida externa, recessão e ajuste estrutural: o Brasil diante da crise. Rio de janeiro: Paz e Terra, 1982.

BACHA, E. L. Os mitos de uma década: ensaios de economia brasileira. Rio de Janeiro: Paz e Terra, 1976.

BACHA, E. L. "IMF and the prospects for maladjustments um Brazil". In: WILLIAMSON, J. (Org.). Prospects for adjustment in Argentina, Brazil and Mexico. Washington, DC: Institute for International Economics, 1983.

BADO, A. R. L. Repensando a dívida externa brasileira no período da Nova República, 1985/1989: análise da moratória até o processo de redução da dívida. Dissertação (Mestrado), Pontifícia Universidade Católica, São Paulo, 1991. 
BAER, M. "A dívida externa brasileira: estratégias de negociação e impactos internos (19831987)”. In: BRESSER-PEREIRA, L. C. (Org.). Dívida externa: crise e soluções. São Paulo: Brasiliense, 1989.

BAER, M.; MACARINI, J. P.; ANDRADE, R. P. “A performance em 1985 e o contexto favorável ao Plano Cruzado". In: CARNEIRO, R. (Org.). Política econômica da Nova República. Rio de Janeiro: Paz e Terra, 1986.

BATISTA JÚNIOR, P. N. Participação brasileira no mercado financeiro internacional: custo e perfil da dívida externa brasileira. Estudos Especiais IBRE, FGV, n. 2, 1981.

BATISTA JÚNIOR, P. N. Mito e realidade da divida externa brasileira. Rio de Janeiro: Paz e terra, 1983.

BATISTA JÚNIOR, P. N. Da crise internacional à moratória brasileira. Rio de Janeiro: Paz e Terra, 1988.

BIASOTO JUNIOR, G. A estatização do endividamento externo e o crescimento da dívida do setor público na primeira metade da década. Belo Horizonte: ANPEC, vol. 3, 1988.

BRANT, C. Quem tem medo da moratória? Rio de Janeiro: Riquel, 1986.

CAMARGO, J. M. "Do Milagre à Crise: A economia brasileira nos anos oitenta". In: ARIDA, P. (Org.). Dívida externa, recessão e ajuste estrutural: o Brasil diante da crise. Rio de janeiro: Paz e Terra, 1982.

CAMARGO, J. M; RAMOS, C. A. A Revolução Indesejada: o Plano Cruzado e o mercado de trabalho. Rio de Janeiro: Campus, 1990.

CAMPOS, A. F. O II PND e o processo de estatização da dívida externa: a crise das estatais e a sua posterior privatização. Raízes, Ano XVIII, n. 19, mai. 1999.

CARNEIRO, D. "Crise e esperança”. In: ABREU, M. P. (Org.). A ordem do progresso: cem anos de política econômica republicana. Rio de Janeiro: Campus, 1992.

CARNEIRO, D. "1974-1994: os desafios da estabilização postergada”. In: LAMOUNIER, B.; CARNEIRO, D.; ABREU, M. P. 50 anos de Brasil: 50 anos de Fundação Getúlio Vargas. Rio de Janeiro: Editora FGV, 1994.

CARNEIRO, D.; MODIANO, E. M. “Ajuste externo e desequilíbrio interno: 1980-1984". In: ABREU, M. P. (Org.). A ordem do progresso: cem anos de política econômica republicana. Rio de Janeiro: Campus, 1992.

DAVIS, R. F. Dívida externa e alternativas de desenvolvimento na América Latina. Revista de Economia Política, v. 5, n. 3, jul./set., 1985.

DAVIS, T. E. As causas e consequências da dívida latino-americana. Revista de Economia Política, v. 4, n. 3, jul./set., 1984.

CASTRO, A. B.; SOUZA; F. E. P. A economia brasileira em marcha forçada. Rio de Janeiro: Paz e Terra, 1985.

COUTINHO, L. G. "Pontos mínimos para uma negociação externa soberana e realista". In: MELLO, J. M. C.; BELUZZO, L. G. M. (Orgs.). FMI x Brasil: a armadilha da recessão. São Paulo: Gazeta Mercantil, 1983. 
CRUZ, Paulo. Dívida externa e política econômica. São Paulo: Brasiliense, 1984.

DIMENSTEIN, G. et al. (Orgs.). O complô que elegeu Tancredo. 7. ed. Rio de Janeiro: JB, 1985.

FISHLOW, A. A economia política do ajustamento brasileiro aos choques do petróleo: uma nota sobre o período 1974/1984. Pesquisa e Planejamento Econômico, n. 16, v. 3, dez. 1986.

FURTADO, C. M. O Brasil pós-“milagre”. Rio de Janeiro: Paz e Terra, 1981.

FURTADO, C. M.A nova dependência: dívida externa e monetarismo. Rio de Janeiro: Paz e Terra, 1982.

FURTADO, C. M. Não à recessão e ao desemprego. Rio de janeiro: Paz e Terra, 1983.

FURTADO, C. M. Transformação e crise na economia mundial. Rio de Janeiro: Paz e Terra, 1987.

FURTADO, C. M. ABC da divida externa. Rio de Janeiro: Paz e Terra, 1989.

KALETSKY, A. Os custos da moratória. Rio de Janeiro: Paz e Terra, 1988.

LAGO, L. A. C. "A programação do setor externo em 1983: uma breve análise crítica". In: ARIDA, P. (Org.). Dívida externa, recessão e ajuste estrutural. Rio de Janeiro: Paz e Terra, 1982.

LAGO, L. A. C. "A suspensão do pagamento dos juros da dívida externa". In: BATISTA JÚNIOR, P. N. (Org.). Novos ensaios sobre o setor externo da economia brasileira. Rio de Janeiro: FGV-IBRE, 1988.

LOPES, F. L. "A crise do endividamento externo: alguns números e suas consequências". In: ARIDA, P. (Org.). Dívida externa, recessão e ajuste estrutural: o Brasil diante da crise. Rio de Janeiro: Paz e Terra, 1982.

MALAN, P. S. "Recessão e renegociação". In: ARIDA, P. (Org.). Dívida externa, recessão e ajuste estrutural: o Brasil diante da crise. Rio de janeiro: Paz e Terra, 1982.

MALAN, P. S. "A questão externa”. In: MELLO, J. M. C.; BELUZZO, L. G. M. (Orgs.). FMI $x$ Brasil: a armadilha da recessão. São Paulo: Gazeta Mercantil, 1983.

MARQUES, M. S. B. FMI: “A experiência brasileira recente”. In: BATISTA JÚNIOR, P. N. (Org.). Novos ensaios sobre o setor externo da economia brasileira. Rio de Janeiro: FGV-IBRE, 1988.

MELLO, J. M. C.; BELUZZO, L. G. M. (Orgs.). FMI x Brasil: a armadilha da recessão. Gazeta Mercantil, 1983.

MOURA, A. R. "Rumo à entropia: a política econômica, de Geisel a Collor". In: LAMOUNIER, B. et al. (Orgs.). De Geisel a Collor: o balanço da transição. São Paulo: Editora Sumaré, 1990.

MUNHOZ, D. G. "Negociação com os bancos credores: a urgência na redefinição de objetivos". In: MELLO, J. M. C.; BELUZZO, L. G. M. (Orgs.). FMI x Brasil: a armadilha da recessão. São Paulo: Gazeta Mercantil, 1983.

NEPOMUCENO, E. O outro lado da moeda: histórias ocultas do Cruzado e da moratória. São Paulo: Siciliano, 1990.

PACHECO, C. A. "O resgate da política econômica: um balanço preliminar do plano de estabilização e de seus antecedentes”. In: AYERBE, L. F.; PACHECO, C. A. O choque econômico e a transição democrática. São Paulo: Vértice, 1986. 
RESENDE, A. L. “A ruptura no mercado internacional de crédito". In: ARIDA, P. (Org.). Dívida externa, recessão e ajuste estrutural: o Brasil diante da crise. Rio de Janeiro: Paz e Terra, 1982.

PORTELLA FILHO, P. Moratória soberana. São Paulo: Alfa-Omega, 1988.

SAMPAIO JÚNIOR, P. A.; AFFONSO, R. "A transição inconclusa”. In: KOUTZII, F. (Org.). Nova República: um balanço. Porto Alegre: L\&PM, 1986.

TAVARES, M. C. T.; ASSIS, J. C. O grande salto para o caos: a economia política e a política econômica do regime autoritário. Rio de Janeiro: Zahar, 1985. 